\title{
Thustý krubovýpeniz se lvem
}

P a v e I G R E G O R

(N) 73,2018, s. $91-96$

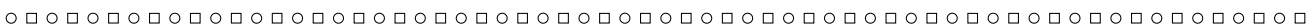

\section{Thick round coin with lion image}

The author presents an unknown double-sided thick round coin with lion and crown images preserved in a private collection. Based on detailed iconographic and material analyses, and on comparison with the contemporary lion / crown types, the author offers the very likely dating of the coin. It was produced before the reform of George of Podébrady, i.e. between 1460 and 1469. The coin also documents the fact that the bellers of George with crown in pearled circle could not have been struck after the reform in 1469, but-very likely - they had been also produced before the reform.

-1 thick round coin; iconography; dating; George I of Podébrady (1458-1471).

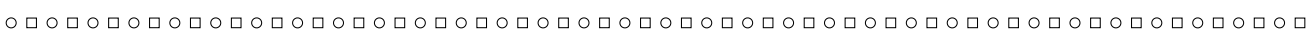
구 tlustý kruhovýpeniz; ikonografie; datace; Jiř́ I. z Poděbrad (1458-1471).

V roce 2014 byl nalezen nedaleko moravské obce Jevíčko etalon kruhového peníze se lvem, který byl podrobně popsán v Numismatickém sborníku. ${ }^{1}$ Rád bych nyní upozornil na další ražbu, která s těmito etalony může souviset. Jedná se o v soukromé sbírce uložený tlustý dvoustranný kruhový peníz se lvem.
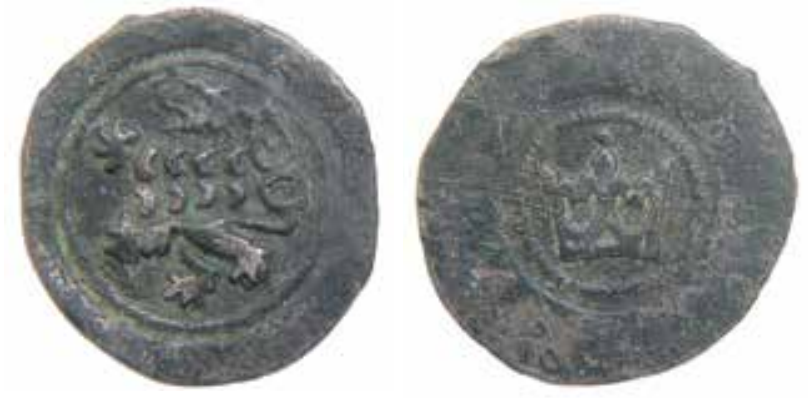

ČECHY, Jiří z Poděbrad (1458-1471), tlustý kruhový peníz se lvem a korunou. Av.: korunovaný dvouocasý lev v hladkém kruhu. Hřiva je složena z 4+4+4 měsíčků.

Rv.: liliová koruna v perlovci. Na vrcholu prostřední lilie se nachází perla. 1. AR; 3,510 g; 18,32 x 17,24 mm; síla stř́žžku 1,72 (min.) - 2,28 (max.) mm.

* Pavel GREGOR, Česká numismatická společnost (pobočka Pražské groše), pa.gregor@tiscali.cz. ČERNOHORSKÝ, Ondřej - UHLÍR̆, Josef - VÍCH, David: Nález mincovního etalonu z Jevíčka (okr. Svitavy), Numismatický sborník 29/1, 2016, s. 109-114 (dále v textu jen Jevíčko). 
Karel Castelin ${ }^{2}$ popisuje dvoustranné peníze se lvem a korunou pod čísly Cast. 55-57. V jeho případě se však nejedná o kruhové peníze, ale o peníze se čtyřrázem.

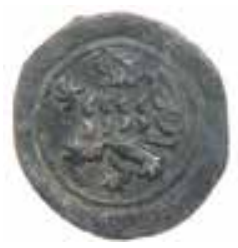

a

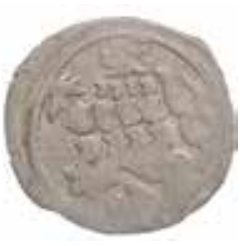

b

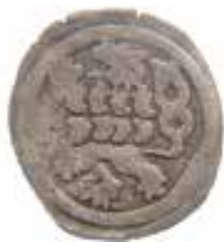

c

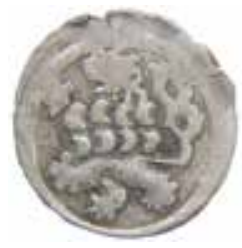

d

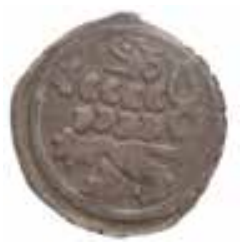

e

- $\sqsubset$ 1: Porovnání provedení Iva na tlustém penízu (a) se základními řadami kruhových penízů se Ivem. Typ Hána III/1 (b), typ Hána IV/1 (c), Typ Hána V/3 (d), Hána V/1 (e).

Přestože je hřiva lva tvořena třemi řadami měsíčků 4+4+4, nelze ji ztotožnit $s$ typem Hána III/1 (Cast. 58). ${ }^{3}$ Hlava typu Hána III je provedena menšími puncy než na zde prezentovaném penízu (porovnej obr. 1a a 1b). Hlava lva je většího provedení, je vyvedená silnou čarou s výrazným okem a uchem. Krátká dolní čelist je mírně zahnutá nahoru, na krku jsou patrné náznaky chlupů. Koruna na hlavě lva je výrazná. Tlama lva neobsahuje jazyk ani zuby. Obrázek 1c-e zobrazuje odlišné provedení dolní čelisti u typů Hána IV (obr. 1c) a Hána V (obr. 1d-e). Shodné provedení tvaru hlavy se vyskytuje u typů Hána V a Hána VI (Cast. 66-68). Dolní smyčka ocasu má tvar pravidelného kruhu. Horní smyčka je protáhlá, zakončená chomáči. Smyčka ocasu není uzavřená. Ocas je k trupu lva napojen silnou, mírně prohnutou linkou, jež se před rozdvojením ocasu ohýbá směrem vzhůru. Tvar ocasu odpovídá tvarům ocasu použivaných u typů Hána III až Hána VI. Pravá přední tlapa je většího provedení s výraznými čtyřmi prsty s prodlouženým zápěstím. Toto provedení se vyskytuje běžně u typu Hána IV (Cast. 67c), ale u typů Hána V a Hána VI se vyskytuje jen zř́dka.

I když tato varianta doposud nebyla oficiálně popsána, je známa, a je zařazena v rozšířené Hánově typologii pod číslem V/4. ${ }^{4}$

2 CASTELIN, Karel: Česká drobná mince doby předhusitské a husitské 1300-1471, Praha 1953 (dále v textu jen Cast.).

3 HÁNA, Jiři: Západo- a jihočeská mincovní privilegia druhé poloviny 15. století. K problémům identifikace mincovní produkce, Sborník Západočeského muzea v Plzni, rada Historie 17, Plzeň 2004.

4 Rukopis GREGOR, Pavel: Kruhový peníz se Ivem - Dodatky k typologii Hána. Zjednodušená verze je dostupná online: http://www.cnspg.cz/public_files/peniz_se_lvem.ppt (30. 8. 2015). 

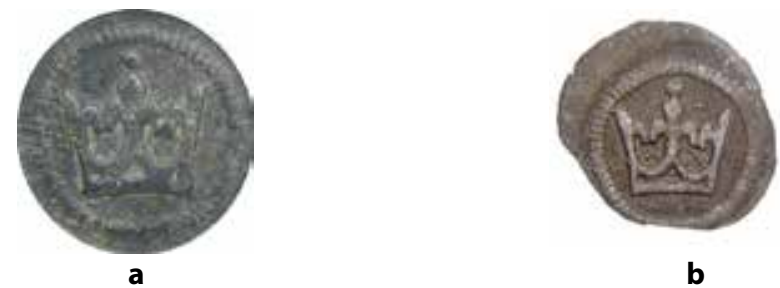

- $[$ 2: Porovnání detailu tvaru koruny na tlustém penízu (a) a haléri s perlovcem (b).

Provedení koruny je zcela shodné s korunami na haléřích s perlovcem. Úzká směrem nahoru se rozšiřující koruna složená z jedné celé a dvou postranních lilií. Nad prostřední lilií je vyražena výrazná perla. Krajní lilie perlu nemají. Čelenka koruny je naznačena spodní mírně prohnutou linkou a dvěma oblouky, které spojují prostřední lilii s krajními. V ploše mezi liliemi nejsou patrny žádné obrazce. $Z$ těchto důvodů ji lze bezpečně přiřadit k typu Rad. I.265 (Cast. 80).

Jak již bylo zmíněno na začátku článku, je vhodné tuto ražbu porovnat i se známými etalony, které zobrazují kruhový peníz se lvem a korunu. V úvahu připadají etalony popsané Smolíkem Sm. $23,{ }^{6}$ etalon nacházející se v Chaurově sbírce ${ }^{7}$ pod č. 382 a nedávno objevený etalon z nálezu Jevíčko 2014.

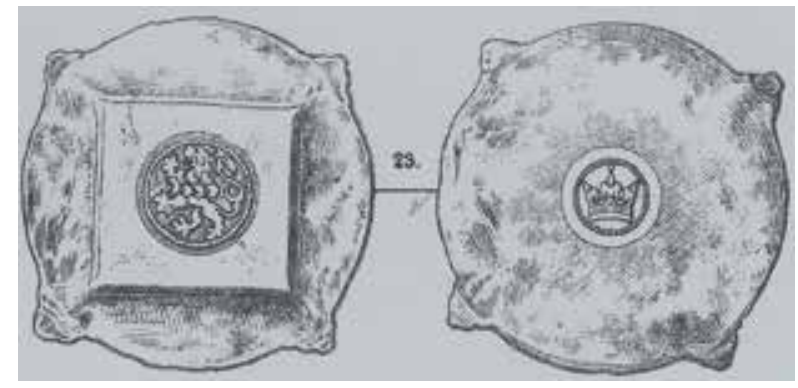

3: Etalon Smolík č. $23 .{ }^{8}$

Z podrobného rozboru Smolíkovy perokresby je zřejmé, že etalon vyobrazený pod číslem Sm. 23 je velmi nepřesný. Pravděpodobně se jedná o zidealizovanou rekonstrukci. Výše prezentovaný etalon nezobrazuje lva v hladkém kruhu, ale v perlovci. Pokud by měl popisovat kruhový peníz v perlovci, pak neodpovídá tvar ocasu lva. Protože ten je u kruhových peněz jiného provedení. Zde prezentovaný ocas pravděpodobně odpovídá svým tvarem ocasům na

RADOMĚRSKÝ, Pavel: Nález mincí z 15. století v Králově Dvoře u Berouna, 2. vyd., Praha 1976 (dále v textu jen Rad.).

6 SMOLÍK, Josef: Pražské groše a jejich dily (1300-1547), 2. dopl. vyd., Praha 1971 (dále v textu jen Sm.).

7 HÁSKOVÁ, Jarmila: České, moravské a slezské mince 10.-20. století. Národní muzeum v Praze - Chaurova sbírka III. Pražské groše (1300-1526), Praha 1991 (dále v textu jen Chaurova sbírka).

8 Obr. 3 převzat z SMOLík, J.: Pražské groše, tabulka II, číslo 23. 
pražských groších Vladislava II. Jagellonského. Také tvar přední pravé tlapy neodpovídá kruhovému penízu v perlovci, ale tvarům tlap používaných na nejstarších kruhových penězích. I když tvar koruny je odpovídající korunám na haléřich, není z výše uvedených důvodů vhodné etalon prezentovaný Smolíkem zahrnout do skupiny uvažovaných etalonů. Pro úplnost zde však byl uveden.

Dalším etalonem je etalon nacházející se v Chaurově sbírce pod číslem 382.?
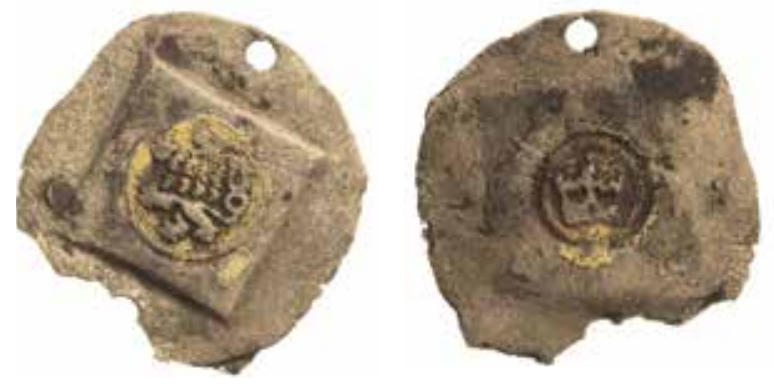

4: Etalon v Chaurově sbírce č. 382.
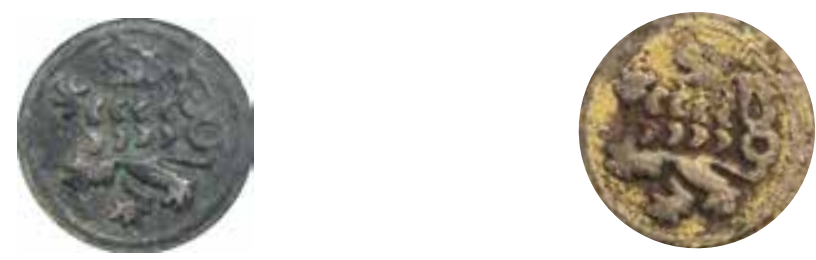

- $\square$ 5: Porovnání detailu Iva tlustého peníze (a) a etalonu z Chaurovy sbírky č. 382 (b).

Etalon z Chaurovy sbírky byl pravděpodobně dodatečně pokoven, takže některé ikonografické prvky jsou nezřetelné. Ale i přesto je zřejmé, že strana se lvem popisována J. Háskovou, jako lev v perlovci, perlovec neobsahuje. Jedná se tedy o hladký kruh. Hřivu lva tvoří tři řady měsíčků 4+4+4. Tvar hlavy je shodného provedení jako u tlustého peníze. Pravá přední tlapa je mohutnější s výraznými čtyřmi prsty. Tvarově je velmi blízká tlapě na zde prezentovaném penízu. Provedení zbývajících tlap nevykazuje odlišnosti od provedení na penízu. I když tvar ocasu je výrazně ovlivněn opotřebením, lze konstatovat, že i v tomto případě je provedení podobné. Zde je na místě upozornit na tvar dolní smyčky ocasu, která v obou případech vykazuje podobné znaky. Dolní smyčka není zcela kruhová, ale na dolní a pravé straně zploštělá, takže jakoby tvořila $\mathrm{v}$ pravé dolní části pomyslný roh čtverce se zakulaceným rohem. Lze tedy vyvodit závěr, že oba lvi pocházejí z časově velmi blízkého období.

\footnotetext{
9 Autorem fotografie etalonu na obr. 4 je Jiří Lehký. Z této fotografie byly také vytvořeny detaily pro obr. 5b a 6b. Sbírka: Národní muzeum, Numismatické oddělení, inv. č. H5-14602.
} 


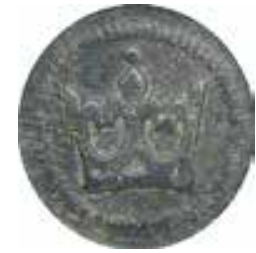

a

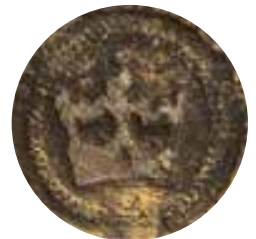

b

6: Porovnání detailu koruny tlustého peníze (a) a etalonu z Chaurovy sbírky č. 382 (b).

Přestože i na straně s korunou je exemplář z Chaurovy sbírky nezřetelný, lze vypozorovat některé zajímavé znaky. Provedení koruny je podobné s provedením na haléřich s perlovcem. Nelze určit, jestli mezi liliemi jsou vyryté nějaké znaky, či nikoliv. Při podrobnějším zkoumání koruny je viditelné, že pravý oblouk spojující prostř̌ední lilii s krajní je výraznějši a je posazen níže, než levý. Tato anomálie se na haléř́ch s perlovcem také vyskytuje relativně často.

Posledním etalonem, se kterým je možné zmíněný peníz porovnat, je etalon z nálezu Jevíčko 2014, který je uložen ve sbírkách Regionálního muzea v Litomyšli. ${ }^{10}$
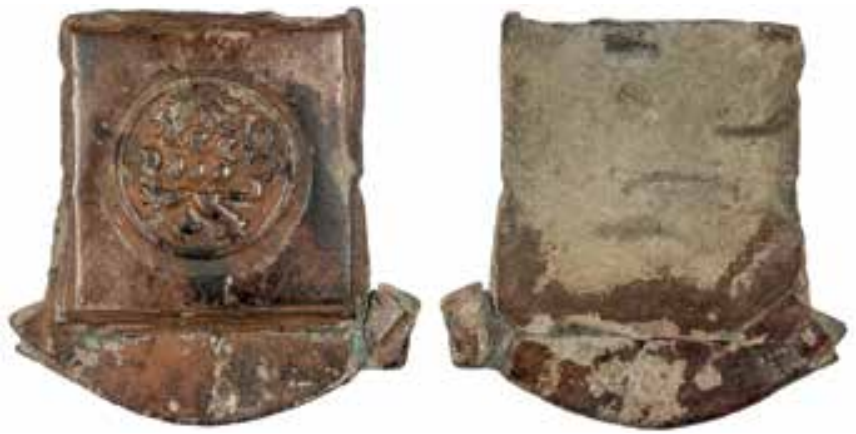

๑7: Etalon z nálezu Jevíčko 2014.

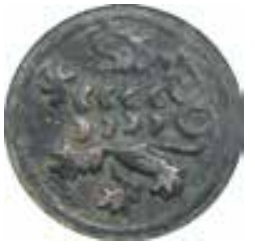

a

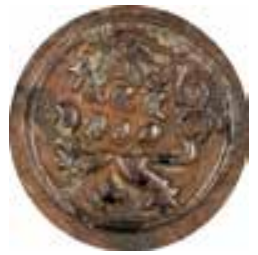

b

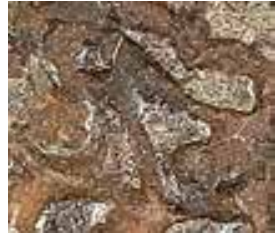

C

8: Porovnání detailu tlustého peníze (a), etalonu Jevíčko (b) a detailu hlavy z etalonu Jevíčko (c).

10 Autorem fotografie etalonu na obr. 7 je Tomáš Čermák z Regionálního muzea v Litomyšli. Z této fotografie byly také vytvořeny detaily pro obr. 8b-c. 
Etalon z Jevíčka se od předchozího odlišuje tím, že se jedná o jednostranný etalon. Není tedy na něm vyražena strana $s$ korunou. Hlava lva je shodného provedení, jako u tlustého peníze, tak i etalonu z chaurovy sbírky. Je provedena tenkou linkou s výrazným uchem. Dolní čelist je mírně zahnutá nahoru. Hř́vu tvoří dvě řady měsíčků, prričemž horní řada se skládá ze tř́i a dolní ze čtyř měsíčků. Pravá přední tlapa je oddělena. I přes výrazné poškození ji lze ztotožnit s tvary používanými u typu Hána VI. Tvar ostatních tlap je podobného provedení, jako na tlustém penízu. I tento typ lze přesně zařadit do již existujících typologií jako typ Hána VI/2 (Cast. 69).

S ohledem na výše uvedené argumenty lze konstatovat, že provedení typu lva u tlustého peníze se shoduje s provedením u typu Hána V/4. Koruna s perlovcem odpovídá standardnímu provedení Rad. I.26 (Cast. 80). Fotografie hrany tlustého penízu jsou vyobrazeny na obrázku 9. Z celkového provedení penízu je pravděpodobné, že k jeho vytvoření nebylo použito průbojníku, ale postupného ostř́ihání. I když na minci jsou patrné stopy přehnutí materiálu z hrany mince směrem do jejího středu, jež se vyskytuje na několika místech na rubu i líci, nelze je považovat za jednoznačný důkaz stop po klopování. Takže závěry o tom, jestli se jedná o ostříhaný etalon, či zatím nepopsaný tlustý peníz, nelze jednoznačně uzavřít.

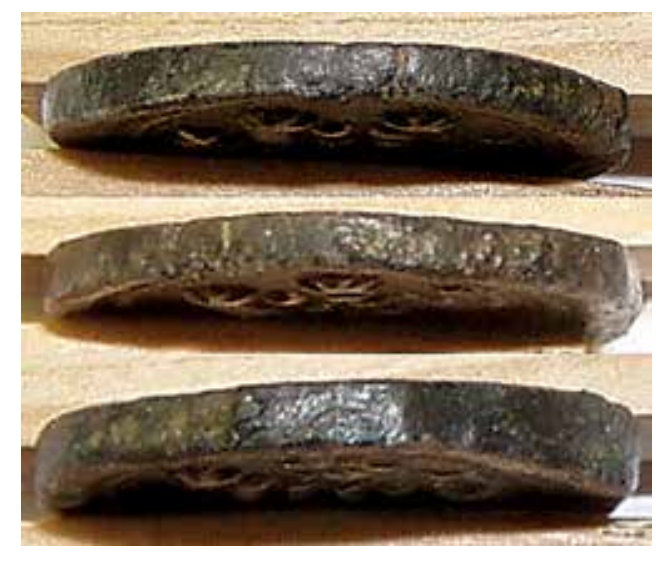

๑ 9: Ukázka hran tlustého peníze.

Dobu vzniku tohoto peníze lze vročit do období před reformou Jiř́ho I. z Poděbrad, tedy mezi roky 1460-1469. Navíc tento peníz poskytuje další důkaz $\mathrm{o}$ tom, že halér s korunou $\mathrm{v}$ perlovci nemohl vzniknout až reformou $\mathrm{v}$ roce 1469, ale že počátek jeho ražby spadá také do staršího období. 

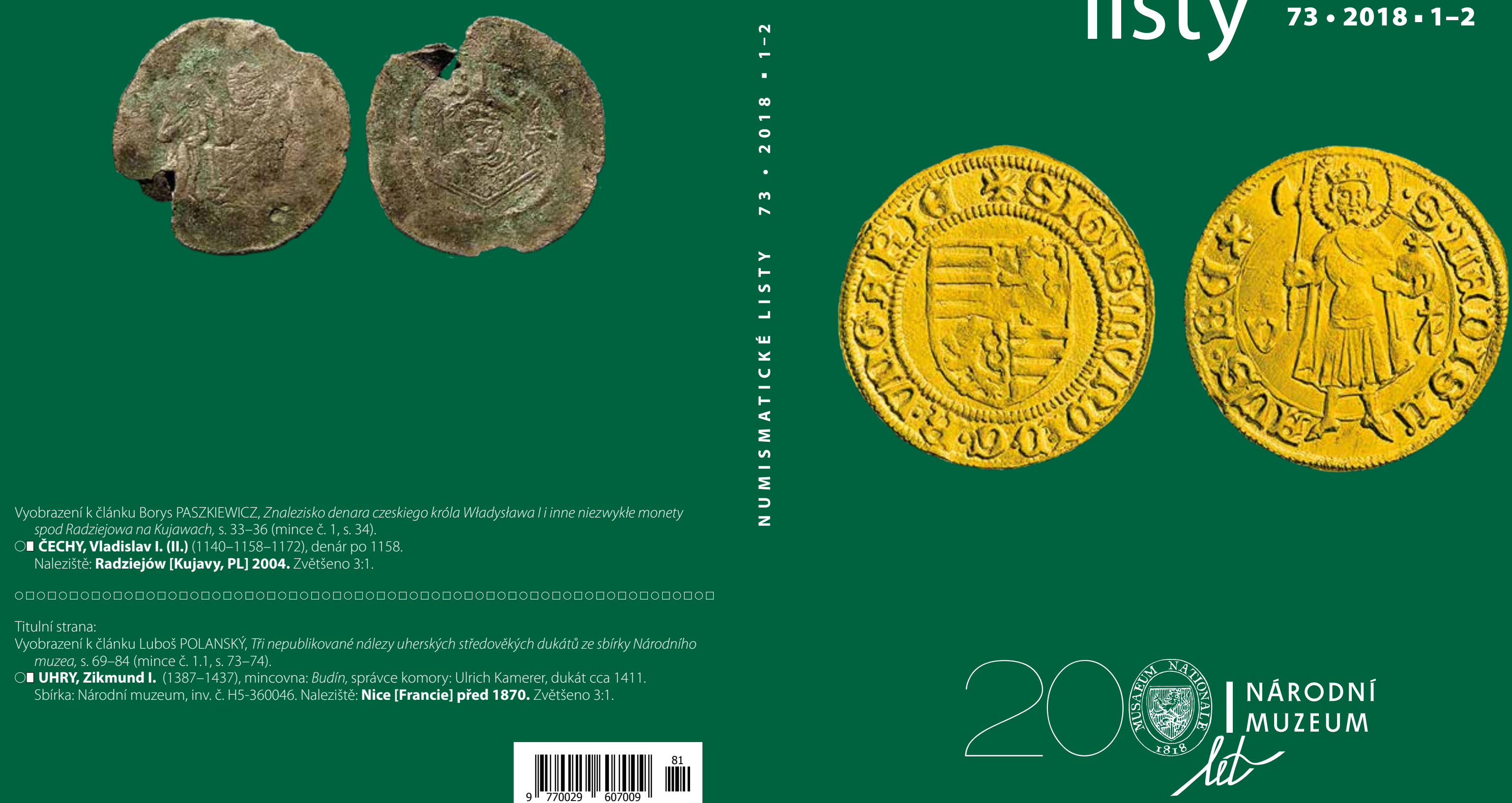
Vedoucí redaktor / Chief Editor: Luboš POLANSKÝ

Redakce / Editors: Michal MAŠEK, Luboš POLANSKÝ, Jiř́ SLÁMA

Redakční rada / Editorial Advisory Board: Marek CAJTHAML, Petr HAIMANN,

Dagmar KAŠPAROVÁ, Jiří MILITKÝ, Věra NĚMEČKOVÁ, Vlastimil NOVÁK,

Borys PASZKIEWICZ, Zdeněk PETRÁŇ, Eduard ŠIMEK, Jan VIDEMAN, Petr VOREL.

Jazyková redakce / Language Editor: Roman LANG.

Kontakt / Contact Address: lubos_polansky@nm.cz • 224497283.

Anglická abstrakta a resumé překládá / English abstracts and summaries translated by Gabriela \& Vlastimil NOVÁK.
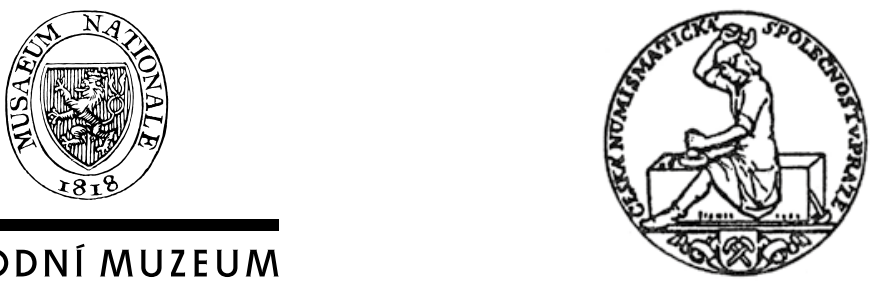

NÁRODNÍ MUZEUM

Vydává: Národní muzeum ve spolupráci s Českou numismatickou společností.

Technická prŕprava a grafická úprava: Quattro-Production s. r. o.

Tisk: Kleinwächter Holding, s. r. o.

Př́mý prodej zajištuje stánek v Nové budově Národního muzea. Distribuci povinných výtisků,

výtisků pro předplatitele a distribuci volných výtisků zajiššuje Obchodní oddělení,

Národní muzeum, Vinohradská 1, 11000 Praha 1, telefon 224497 159, fax 222246047

(ze zahraničí: telefon +420 224497 159, fax +420 222246 047), e-mail: publikace@nm.cz.

Zde se přiiímají i objednávky předplatného, z ČR i ze zahraničí a poskytují informace o cenách

předplatného. Členům České numismatické společnosti zasilá Česká numismatická společnost,

Arménská 1372/10, 10100 Praha 10 - Vršovice, telefon 271730775.

Vychází dvakrát ročně jako dvojčíslo.

Redakční uzávěrky jsou 1. dubna a 1. září.

Pokyny pro autory najdete na www.nm.cz/publikace.

(C) Národní muzeum, Václavské náměstí 1700/68, 11000 Praha 1 - Nové Město.

ISSN 0029-6074 (print), 2533-5650 (online), MK ČR E 568. Praha 2019.
1.1. ČECHY, Boleslav II., Cach 89.

Naleziště: Bodzia, hrob D162 [PL].
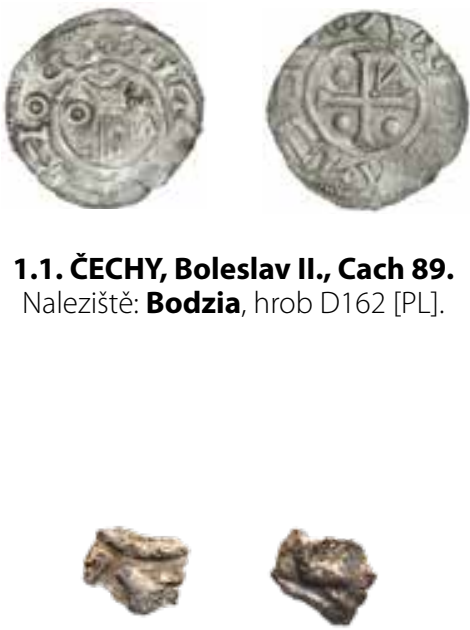

2.1. ČECHY, Vladivoj I., Cach 219-221? Nalezišstě: Dziekanowice, hrob 4/06 [PL]. Zvětšeno 2:1

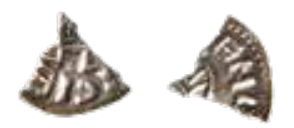

2.3. ČECHY, Spytihněv II., Cach 330 Naleziště: Dziekanowice, hrob 26/99 [PL]
1.3. ČECHY, Boleslav III., Cach 194. Naleziště: Bodzia, hrob E864/II [PL].

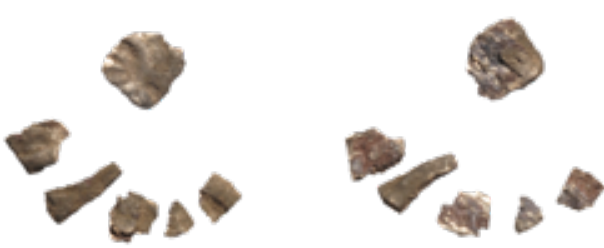

2.2. ČECHY, Břetislav I, Cach 324? Naleziště: Dziekanowice, hrob $27 / 96$ [PL] Zvětšeno 2:1

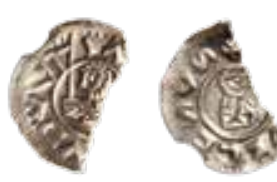

2.4. ČECHY, Vratislav II., Cach 346 Naleziště: Dziekanowice, hrob 28/10 [PL] 


\section{O b s a h}

$\square$ Michal MAŠEK

Významné životní jubileum Zdeňka Petráně.

$\square$ Michal MAŠEK

Portréty na mincích pergamských vládců

Portraits on coins of the rulers in Pergamon...

$\square$ Jiří SLÁMA

K počátkům peněžní smèny $v$ Čechách

Notes to the beginning of the monetary exchange in Bohemia

$\square$ Vojtěch BRÁDLE

Poznámky k rozebrání denárového depotu z Čistèvsi (okr. Hradec Králové)

Some notes to the dispersal of the hoard of deniers from Čistěves (Hradec Králové district)

$\square$ Stanisław SUCHODOLSKI

Czeskie monety z X-XI wieku z cmentarzysk

w miejscowościach Bodzia i Dziekanowice (Polska)

Bohemian coins of the 10-1 $11^{\text {th }}$ centuries from the cemeteries

in Bodzia and Dziekanowice (Poland)

- $\square$ Borys PASZKIEWICZ

Znalezisko denara czeskiego króla Władysława I i inne niezwykłe monety

spod Radziejowa na Kujawach

The find of the denier of King Vladislaus I of Bohemia and other unusual coins

from the area of Radziejów in Kuyavia (Poland)..

$\square$ Marek BUDAJ

Strieborné mince Žigmunda I. Luxemburského (1387-1437)

a ich dopad na uhorské menové pomery

Silver coins of Sigismund I of Luxembourg (1387-1437)

and their impact on the Hungarian monetary situation

$\square$ Luboš POLANSKÝ

Tři nepublikované nálezy uherských středověkých dukátů ze sbírky Národního muzea

Three unpublished finds of the Hungarian medieval ducats from the collection of the National Museum

○ojtěch BRÁDLE - Radek NOVÁK

Dvojice novějších grošových nálezů z Úpicka (okr. Trutnov)

Two most recent hoards containing grossi found in the Úpice region (Trutnov district).

- $\square$ Pavel GREGOR

Tlustý kruhový peníz se lvem

Thick round coin with lion image

$\square$ Jiří RYANT

Hodnocení Josefa Smolíka z roku 1915

Characteristic of Josef Smolik dating to 1915 